\title{
SINDBAD THE SURVIVOR
}

\author{
RÓBERT SIMON* \\ (Budapest)
}

\begin{abstract}
The paper critically reassesses the old and new data which may well be used with due foresight for dating the seven Sindbad tales as well as for putting this small collection of tales with its rather ambiguous hero into its proper social and aesthetic context. In doing this literary reassessment the author tries to restrain himself from the pitfalls of modernising which are hard to avoid in the case of such a seemingly modern personage like Sindbad the Sailor.
\end{abstract}

Key words: Place and time of origin; sources and influences; Sindbad the man; fate and character; the problem of violence.

Perhaps the best-known and most influential discrete unit of that perennial favourite, The Thousand and One Nights, popularly known as The Arabian Nights, is the Sindbad cycle, recounting the story of the hero's seven voyages. A significant number of the motifs around which all of the seven tales are built have been cherished topoi of both literature and folk tradition since Homer, or rather, from the time of the earliest shipwreck story, The Shipwrecked Sailor, written in Egypt at the time of the New Kingdom. ${ }^{1}$ The manner and air of the presentation however, the fact that formally it follows the meandering style of maqām-compositions, the sophisticated narrative technique (the use of both the first and the third person singular), and the hero's enigmatic personality (though he himself tells the story of his life and exploits, he gives us no clue as to his character) - all this and more make Sindbad and his adventures unique and inimitable. Little wonder that they have become the symbols - for authors as diverse as Melville, Joyce, Proust and Borges, and, among Hungarian novelists, Gyula Krúdy and Milán Füst - of perpetual restlessness and yearning for the unknown, for that Utopia beyond the sunset that is most like Paradise on

${ }^{*}$ Róbert Simon, H-1065, Budapest, Bajcsy-Zs. út 31, Hungary.

${ }^{1}$ Its commented English translation is to be found in: W. K. Simpson (ed.): The Literature of Ancient Egypt. An Anthology of Stories, Instructions, and Poetry. New Haven-London, Yale University Press, 1973, pp. 50-56. The Shipwrecked Sailor is regarded as the first narrative of an unreal story (a sort of psychological journey) which, moreover, displays a story within another story. 
earth, ${ }^{2}$ the symbols, in short, of that impossible dream where near merges into far, and the past into the present.

\section{Authorship, place and time of origin, and the variants of the text}

The Arabian Nights grew into its present form over a span of at least seven hundred years, with both the core material changing over time, and newer stories and cycles being added to the original tales. The earliest date we can tie it to is the Papyrus No. 17618 at the Oriental Institute of the University of Chicago. Published by Nabia Abbott $^{3}$ in 1949, the document has been dated to a. H. 266/AD 879, and contains the title page - A Thousand Nights (the 1001st would be added later) - and the beginning of the frame story. A closing date of a very provisional sort is provided by the date of origin of the oldest coherent manuscript of the (Thousand and One) Arabian Nights that has come down to us: three volumes in the Bibliothèque Nationale in Paris (Nos 3609, 3610 and 3611, containing 70, 67 and 87 folio sheets, respectively), which must be dated to between 1450 and 1536. It is on these three volumes that Antoine Galland (1646-1715) based his translation (1704-1717), ${ }^{4}$ at least the first seven tomes; the original Arabic text did not appear in print until Muhsin Mahdi published all three volumes in $1984 .^{5}$

The difficulty of reconstructing the original Arabic text in its entirety will become clear if we consider that even these three volumes contain only the first 271 nights, and so do not, for example, include the Sindbad cycle. Antoine Galland had already translated these stories (in 1701) from another manuscript. After completing their translation, he learned that they were part of a larger collection, and decided not to publish them. As he noted in a letter to the Marquise d'O.: "Avant de commencer l'impression, j'appris que ces contes étaient tirés d'un receuil prodigieux de contes semblables, en plusieurs volumes, intitulé les Mille et Une Nuit. Cette découverte m'oblige de suspendre cette impression, et mettre en français le premier volume que voici, de quatre seulement qui m'ont été envoyés.",

The Sindbad stories that Galland had translated were from an Arabic manuscript known as the "A" text (it is this that would later serve as the basis of the first

${ }^{2}$ Cf. Ernst Bloch: Das Prinzip Hoffnung. Frankfurt, Suhrkamp, 1967, pp. 873-929.

3 "A Ninth-Century Fragment of the 'Thousand Nights'. New Light on the Early History of the Arabian Nights". JNES VIII (1949), pp. 129-164.

${ }^{4}$ Antoine Galland: Les Mille et une Nuit, 12 vols, Paris: chez la Veuve de Claude Barbin, $1704-1717$.

${ }^{5}$ The Thousand and One Nights (Alf Layla wa-Layla) from the Earliest Known Sources. Arabic text Edited with Introduction and Notes by Muhsin Mahdi. Part 1: Arabic Text; Part 2: Critical Apparatus, Description of Manuscripts. Leiden, E. J. Brill, 1984. It is on this edition that H. Haddawy based his fine translation: The Arabian Nights. New York-London, W. W. Norton, 1990.

${ }^{6}$ See Galland's letter of 1701 in: Les Mille et Une Nuits. Contes arabes traduits par Galland. Éd. revue et préfacée par G. Picard, Éd. Garnier Frères, 1960, I, p. XXX. 
Calcutta edition of The Arabian Nights). The "A" variant differs significantly from the more extensively known "B" text, the variant used by the editors of the Būlāq, the second Calcutta, and the Breslau ${ }^{10}$ editions. More than likely, the "A" variant is the older one: the wording is simpler and more terse, the stories contain fewer details, and the dialogues are more laconic. The two variants also differ in how the Sixth Voyage ends, and in their accounts of the entire Seventh Voyage. In the "A" variant, we are explicitly told that Sindbad was washed ashore in Sarandīb (i.e. Ceylon): it is the King of Sarandīb who sends gifts to the Caliph Hārūn ar-Raš̄īd. Sindbad then undertakes the Seventh Voyage - in the "A" variant - specifically at the caliph's behest, who wants to send presents to the King of Sarandīb in return. Fulfilling his mission Sindbad is determined to return home without stopping for the usual barter and trade, but falls into the hands of pirates, who sell him as a slave. His master uses his skills in elephant-hunting. Sindbad is, however, caring for the beasts who, in return, lead him to their secret place full of ivory. Disclosing to his master what he has been shown, he is rewarded and allowed to leave for home. Upon his return to Baghdad, Sindbad tells the caliph of his adventures, and then settles down, to travel no more. The cycle, thus, concludes with a voyage that is much better motivated than in the "B" version.

Of the best-known European translations, Galland's was based upon the "A" text; Payne, ${ }^{11}$ Littmann $^{12}$ and Csilla Prileszky in her Hungarian rendering ${ }^{13}$ consis-

${ }^{7}$ The Arabian Nights' Entertainments In the Original Arabic. Published under the Patronage of the College of Fort William; By Shuekh Uhmud bin Moohummud Sheerwanee ool Yumunee. Calcutta, vol. 1: 1814; vol. 2: 1818.

${ }^{8}$ Alf layla wa-layla, 2 vols, Būlāq, 1251/1835.

${ }^{9}$ The Alif Laila or Book of the Thousand Nights and One Night, Commonly known as "The Arabian Nights' Entertainments", now, for the first time, published complete in the original Arabic, from an Egyptian Ms. brought to India by the late Major Turner Macan, editor of the "Shah Nameh". Ed. by Sir W. H. Macnaghten, 4 vols, Calcutta, W. Thacker and Co. St. Andrew's Library, London, Wm. H. Allen and Co., 1839-1842. Repr. in eight vols, Cairo, 1996-1997. It was Djamāl alGhītānī, the well-known Egyptian writer who took charge of this edition after having realised that there is not a usable text edition in Egypt of the 1001 Nights, cf. his own report in: al-Akhbār, 8th September 1998. The reprint appeared in his well-conceived series called "adh-Dhakhā̄ir", nos 11-18.

${ }^{10}$ Tausend und Eine Nacht arabisch. Nach einer Handschrift aus Tunis herausgegeben von Dr. Maximilian Habicht 12 vols (the first eight volumes edited by M. Habicht [1825-1838], the last four volumes published by H. L. Fleischer [1842-1843]). Breslau, bei Josef Max und Comp., 1825-1843. See to this recension: D. B. Macdonald: Maximilian Habicht and his Recension of the Thousand and One Nights. JRAS (1909), pp. 686-704.

${ }^{11}$ The Book of the Thousand Nights and One Night, now first completely done into English prose and verse, from the original Arabic by John Payne, 9 vols, London, Villon Society, 18821884. Three supplementary volumes: Tales from the Arabic of the Breslau and Calcutta editions of the Book of the Thousand Nights and One Night. London, 1884: and vol. 13: Alaeddin and the Enchanted Lamp. Zein ul Asnam and the King of the Jinn. London, 1889.

${ }^{12}$ Enno Littmann: Die Erzählungen aus den Tausendundein Nächten, zum ersten Mal nach dem arabischen Urtext der Calcuttaer Ausgabe aus dem Jahre 1839 übertragen. 6 vols. Leipzig, Insel Verlag, 1921-1928.

${ }_{13}$ Az Ezeregyéjszaka meséi. Az eredeti arab szöveg első teljes magyar fordítása (The Tales of Thousand and One Nights. The first complete Hungarian rendering made of the original Arabic text). The first three volumes have appeared so far (Budapest, Atlantisz Könyvkiadó, 1999-2000). 
tently used the " $\mathrm{B}$ " variant (Littmann indicated where the two texts differed in his notes). Lane ${ }^{14}$ relied on the "B" text to the end of the Sixth Voyage, and then switched to the "A" variant for the Seventh Voyage (contrasting it with the "B" variant in notes). Richard Burton ${ }^{15}$ was rather free in his treatment of the two texts: for the first five voyages, he used the "B" version of the second Calcutta edition; for the Sixth Voyage, he used both texts, but without any reference to this fact in his notes; while for the Seventh Voyage, he went back to only the "B" text.

The texts leave no doubt that the Sindbad stories originated in either Basra or Baghdad, both of them centres of the handicrafts and long-distance trade that flourished in the early days of the Abbasid caliphate. Baghdad - which the Arabs called Gannat al-ard (Paradise on Earth), and the Persians Behešt-ābād (The Site of Paradise) - was founded in 762 by Caliph al-Manșūr, the second ruler of the Abbasid dynasty, and soon assimilated the over forty settlements in its vicinity. It was the undisputed capital of the caliphate in every respect. At the pinnacle of its wealth and prosperity - from the time of Caliph al-Mahdi (775-785) to the time of Caliph alMa'mūn (813-833) - Baghdad was the residence of not just the caliph and his entourage, but also the affluent administrative and military aristocracy. Craftsmen and tradesmen flocked to the city to supply their need for staples and luxury goods of every kind, and for some time, a veritable middle class seemed to be in the making. ${ }^{16}$ The position of this "bourgeoisie", however, was most precarious, and even at the best of times its accumulated wealth was insufficient to earn an influence in terms of social status or prestige. For all that, the city continued to grow: by around the tenth century, it had a population of a million and a half. By the end of the ninth century, 30,000 ships sailed in and out of its harbour every year; there was an estimated number of between 5000 and 27,000 baths, and according to some sources, the number of mosques in the city reached $100,000 .{ }^{17}$

Founded in 637 or 638 , Basra was at the point of intersection of the trade routes to Iran, Syria and the Arabian Peninsula. A centre of maritime trade, famed far and wide, it was the unquestioned ruler of the Persian Gulf from the middle of the eighth to the last third of the ninth century, and a must for every seafaring merchant

This new outstanding rendering based upon the second Calcutta is planned to be published to the end of 2000 in seven volumes.

${ }^{14}$ The Thousand and One Nights, commonly called in England The Arabian Nights' Entertainment, a new translation from the Arabic with copious notes by E. W. Lane, 3 vols. London, C. Knight and Co., 1839-1841.

${ }^{15}$ Richard F. Burton: A plain and literal translation of the Arabian Nights Entertainments, now entitled The Book of the Thousand Nights and a Night. 10 vols. Benares, Kamashastra Society (Actually London), 1885; and Supplemental Nights to the Book of the Thousand Nights and a Night, with Notes Anthropological and Explanatory, 6 vols. Benares, 1886-1888.

${ }^{16}$ See S. D. Goitein: The Rise of the Middle-Eastern Bourgeoisie in Early Islamic Times, and The Mentality of the Middle Class in Medieval Islam, in his Studies in Islamic History and Institutions. Leiden, E. J. Brill, 1966, pp. 217-254; E. Ashtor: A Social and Economic History of the Near East in the Middle Ages. Berkeley-London, University of California Press, 1976, pp. 109-114.

${ }^{17}$ Cf. Encyclopaedia of Islam, s.v. Baghdād (A. A. Duri), 1997, vol. I, pp. 925-926. See also G. Le Strange's still seminal Baghdad during the Abbasid Caliphate. Oxford, Clarendon Press, 1900; Reprint: 1972. 
to visit. Very few of the commodities of the world trade of that time were missing from the bazaars lining the navigable channels of Basra.

The stories of The Arabian Nights set in Baghdad paint a colourful picture of what life must have been like in the two cities: the hustle and bustle, the everyday customs and the ceremonial occasions - so much so that a number of cultural historians have attempted to reconstruct the social and cultural scene of the time on the basis of these descriptions. ${ }^{18}$

As for the work's authorship, certain scholars have held the Sindbad cycle to have been the product of collective endeavour, with only two of the stories - so argues P. Casanova, for instance forming the original core, and the rest added over the centuries, the authors of each one elaborating on the original motifs. ${ }^{19} \mathrm{~N}$. Elisséeff, too, is of the opinion that the work was produced over a long period of time. ${ }^{20} \mathrm{M}$. Gerhardt, on the other hand, decidedly maintains that the painstaking precision of the narrative and its symmetrical structure provide conclusive proof that only one author was involved; ${ }^{21}$ while F. J. Gazoul in her structuralist approach does not even address the hypothesis of the work's collective authorship. ${ }^{22}$ Judging by the personal tone of the Sindbad cycle, certainly, and by the analogous structure of each of the seven voyages, I too, am inclined to think that we are having to do with a single author. This, of course, is by no means to suggest that there were no subsequent additions, deletions or emendations - indeed, the two extant variants make it clear that there were plenty of all three. But whoever the single author was, we can be certain - M. J. de Goeje ${ }^{23}$ has pointed out - that he was not someone who had actually sailed the seas, or had had first-hand experience of a voyage from Basra to India or Ceylon. The text is too full of geographical and other absurdities. The author it seems had taken the tales told by sailors for his raw material, and fashioned them into the adventures of a single hero.

The probable time of the Sindbad cycle's origin can be delimited with a considerable degree of certainty. ${ }^{24}$ It had to have been conceived after the middle of the

${ }^{18}$ Cairo is the focus of E. W. Lane's notes, and the book based on them: Arabian Society in the Middle Ages. Studies from the Thousand and One Nights. Ed. S. Lane-Poole. London, Barnes and Noble, 1883; Reprint: 1971. R. Irwin discusses life in Baghdad, too, at some length in his: The Arabian Nights. A Companion. London, Penguin Books, 1994, pp. 122-126, and passim. For the maritime trade cantered on Basra, see Marek Meissner: Die Welt der sieben Meere. Auf den Spuren arabischer Kaufleute und Piraten. Leipzig, G. Kiepenheuer, 1987, pp. 87-102. For Basra as an intellectual centre, see Ch. Pellat: Le milieu bașrien et la formation de Ğăhiz. Paris, A. Maisonneuve, 1953. The entry of $E I^{2}$ on Bașra in Classical period (written also by Ch. Pellat) doesn't contain much new material $\left(E I^{2}\right.$, vol. 1, pp. 1127-1129)

${ }^{19}$ P. Casanova: Notes sur les Voyages de Sindbad le Marin. Bulletin de l'Institut Français d'Archéologie Orientale du Caire, 1922, pp. 113-198.

${ }^{20}$ N. Elisséeff: Thèmes et motifs des 1001 Nuits: essai de classification. Beyrouth, Institut Français de Damas, 1949, p. 41.

${ }^{21}$ M. Gerhardt: The Art of Story-Telling. A Literary Study of the Thousand and One Nights. Leiden, E. J. Brill, 1963, p. 257.

${ }^{22}$ F. J. Ghazoul: Nocturnal Poetics. The Arabian Nights in Comparative Context. Cairo, The American University in Cairo Press, 1996 (first edition: Cairo, UNESCO, 1980), pp. 68-81.

${ }^{23}$ M. J. de Goeje: De reizen van Sindebaad. De Gids 53 (1889), p. 309.

${ }^{24}$ See T. Nöldeke: Zu den ägyptischen Märchen. ZDMG 42 (1888), pp. 68-72; M. J. de Goeje, op. cit., p. 310; P. Casanova, op. cit., pp. 148-168; E. Littmann, op. cit., XII, p. 715; N. 
ninth century, ${ }^{25}$ and no later than the twelfth century. The most compelling evidence of the former is the sundry borrowings from a work - Kitāb al-masālik wa'l-mamālik (The Book of the Roads and Countries) ${ }^{26}$ - by the Iranian-born geographer, Ibn Khordādhbeh, who was postmaster and chief of intelligence (șähib al-barīd wa'l-h̆abar) to the Caliph al-Mu ${ }^{c}$ tamid (870-892). J. M. de Goeje dates the first redaction of The Book of the Roads and Countries to 846; the second redaction, with additions, appeared in $885 .^{27}$ Our "no-later-than" date is based on the several passages in al-Qazwīn̄i (1203-1283) 'A ${ }^{c} \bar{g} \bar{a} i^{\circ} b$ al-mahlūqāt wa-ātār al-bilād (The Marvels of Creation and Monuments of the Lands) which the rather credulous geographer seems to have taken directly from the stories of Sindbad's voyages. This - and other considerations have impelled J. M. de Goeje (and following him, M. Gerhardt) to date the forming of the Sindbad cycle to the end of the ninth or the beginning of the tenth century. Grunebaum, too, concurs with de Goeje, and puts the time of authorship at no later than 900; while T. Nöldeke (and N. Elisséeff) likewise date the work to no later than the tenth century.

There is, however, one important piece of circumstantial evidence which narrows down the time frame a little more, and makes it very likely that the Sindbad stories were composed a few decades after 878 . The hundred years or so from the last third of the eighth century to 878 saw a great deal of very active trade between the Muslim East and China. This at least, is the picture that emerges from the many colourful, but apparently largely credible, Muslim sources, particularly the Ahbār aṣSin wa'l-Hind (Stories about China and India), compiled in $851{ }^{29}$ Up until 795, Can-

Elisséeff, op. cit., p. 41; E. von Grunebaum: Medieval Islam. A Study in Cultural Orientation. Chicago, The University of Chicago Press, 1961, p. 298; M. Gerhardt, op. cit., p. 241: $E I^{2}$, s.v. "Sindbād" (U. Marzolph), vol. IX, p. 639. A hitherto neglected information in Manūchehrī's Dīwān shows that at the beginning of the 11th century (the poet died in 1040-1041) Sindbad's voyages have been used even in the Persian poetry as a well-known literary topic, see the qașīda n. 11, 1. 16 in A. de Biberstein-Kazimirski's Edition (Paris, 1886).

${ }^{25}$ Taking his cue from the direct reference in the Sixth Voyage, P. Casanova is the only authority to date the work to the time of Hārūn al-Rašīd.

${ }^{26}$ Ibn Khurradadzbih (Khordādbeh): Kitāa al-masālik wa'l-mamālik. 1889, Leiden, E. J. Brill.

${ }^{27}$ See M. J. de Goeje's French-language introduction to the Arabic edition, pp. XVIII-XX.

${ }^{28}$ This early date is what made Nöldeke, for instance, believe that the Sindbad cycle was a part of The Arabian Nights already in its Baghdad phase.

${ }^{29}$ Ahbār as Șin wa'l-Hind. Relations de la Chine et de l'Inde, rédigée en 851. Texte établi, traduit et commenté par J. Sauvaget. Paris, Société d'Édition 'Les Belles Lettres', 1848. Sauvaget gives a brief overview of this trade. Further data to the Arab-Chinese trade before 878 see H. Yule: Cathay and the Way Thither, revised by H. Cordier, New Delhi, Munshiram Manoharlal, 1998 (first) published by the Hakluyt Society, London, 1916). I, pp. 83-92; Hādī Hasan: A History of Persian Navigation. London, Methuen, 1928, pp. 104-106 (he overstressed the Persian presence in this trade which has been contested by J. Sauvaget, op. cit., pp. XXXV, sq); G. F. Hourani: Arab Seafaring in the Indian Ocean in Ancient and Early Medieval Times. Princeton, N.J., Princeton Univ. Press, 1951, pp. 64-78; M. Meissner, op. cit., pp. 87-102; E. Ashtor, op. cit., pp. 105-109; S. M. Yusuf: The Route of Arab Mariners through al-Zābaj (Further India) in the Third and Fourth Century a. H.; Ceylon and the Arab Trade. In: Studies in Islamic History and Culture, Delhi, Adam Publishers, 1989, pp. 131-155, pp. 156-168; A. Schottenhammer: The Maritime Trade of Quanzhou (Zaitun) from the Ninth through Thirteenth Century. In: Himanshu Prabha Ray (ed.): Archae- 
ton was the main entrepot; after that, it was Hangchow (South of Shanghai). If the above sources are to be believed, Hangchow had a foreign - primarily Muslim population of between one and two hundred thousand throughout much of the ninth century. A revolt broke out in 875 , however, and turned against the foreigners in 878: the massacre of tens of thousands of non-Chinese merchants and traders at that time effectively put an end to maritime trade to China. After that, Arab merchants would sail no farther than Calicut on the Malabar coast in Kerala, or perhaps the Southwestern coast of Ceylon (Sarandīb). Reading the Sindbad cycle, one is immediately struck by the fact that there is no mention at all of China - which would lead one to conclude that the stories would have had to be compiled subsequent to the events of $878 .^{30}$

\section{Sources and influences}

"It is hardly an exaggeration to say that every single ethnological or frankly legendary trait used by the unknown author or redactor can be amply paralleled from both Eastern and Western literatures", Gustave E. von Grunebaum writes, analysing the motifs of the Sindbad cycle. ${ }^{31}$ The presence of such "migrant motifs" in itself, however, reveals very little about the form of the work, and the value system behind it. It is the context in which these borrowings occur that tells us something of the cultural milieu. ${ }^{32}$ Thus, for instance, the "fish-island" motif of the First Voyage is one that occurs also in the Historia Alexandri Magni attributed to Pseudo-Callisthenes. ${ }^{33}$ There, however, it figures as a not-too-felicitous piece of etiology, as well as an illustration of hetaireia, the spirit of self-sacrifice for love of one's mates. Much the same motif is elaborated in Buzurg ibn Šahriyār's mid-tenth century Kitāb ${ }^{c} a \breve{g} \bar{a}$ 'ib al-Hind, a set

ology of Seafaring. The Indian Ocean in the Ancient Period. Delhi, Pragati Publications, 1999, pp. 271-290.

${ }^{30}$ M. J. de Goeje makes reference to this event in his excursus to the Kitā $b^{c}$ ağ $\bar{a}$ 'ib al-Hind, and R. Henning speaks of it as well. Cf. Buzurg ibn Šahriyār, Kitāa ${ }^{c} a \bar{g} \bar{a}$ 'ib al-Hind. Livre des Merveilles de l'Inde. Texte arabe par P. A. van der Lith, traduction française par L. Marcel Devic. Leiden, E. J. Brill, 1883-1886; R. Henning: Terrae Incognitae. Eine Zusammenstellung und kritische Bewertung der wichtigsten vorcolumbischen Entdeckungsreisen an Hand der darüber vorliegenden Originalberichte, vol. II. Leiden, E. J. Brill, 1950, pp. 119-201.

${ }^{31}$ Grunebaum, op. cit., p. 298. Grunebaum considered Muslim culture to be syncretistic without originality - a view that had rightly been criticised by the more recent, mainly Arab, research, see A. Laroui: Les arabes et l'anthropologie culturelle, remarques sur la méthode de Gustave von Grunebaum. In: La crise des intellectuels arabes, Traditionalisme ou historicisme? Paris, F. Maspéro, 1974, pp. 59-102; B. S. Turner: Gustave E. von Grunebaum and the Mimesis of Islam. In: A. Hussain - R. Olson - J. Qureshi (eds): Orientalism, Islam, and Islamists. Brattleboro, Vermont, Amana Books, 1984, pp. 193-201; Ghazoul, op. cit., 1966, pp. 13ff.

${ }^{32}$ Ghazoul's structuralist approach (op. cit., pp. 1-54) attributes The Arabian Nights a more unified structure than there is evidence for and assumes of its authors a more programmatic approach than is likely. Originally, in fact, the various cycles which make up the work had much less reference to one another. For a much more sensitive treatment of the sui generis aspects of the text, see R. Irwin (op. cit., pp. 214-236).

${ }^{33}$ Ed. by W. Kroll, Berlin, 1926, III. 17. 3-7. See also Grunebaum, op. cit., p. 298. 
of 134 sailor-stories, ${ }^{34}$ in effect a collection of well-told anecdotes, with little more in the way of a message than that a sailor had better keep his eyes peeled. Sindbad's "fish-island" story, on the other hand, conveys what must have been the fundamental life experience of the post-tenth-century urban middle class: a sense of utter insecurity and uncertainty. The belief that anything can happen, and that essentially, it can turn out at any moment, about just about anything, that nothing is, in fact, what it seems to be. As Antal Szerb observed in connection with The Arabian Nights: "The basic mood is existential uncertainty. Insecurity on a scale that borders on the irrational... Everything is possible - everything that's awful. Every story illustrates that destiny is a force whose power is beyond imagining. Man has a will only so that everything might turn out the exact opposite of what he wills." 35

The issue of sources and influences was already raised by A. Galland, who also identified the Polyphemus motif in Sindbad's Third Voyage. ${ }^{36}$ In the Fourth Voyage, on the other hand, it is the Circe motif that one is reminded of, when Sindbad and his fellows are offered magical food with powers to deprive one of one's free will. ${ }^{37}$ For all that, there is no real evidence that Homer was known in Baghdad in the tenth century. While the Muslim adoption of the science and philosophy of classical Greece forms one of the most significant chapters in the survival of the Hellenic tradition, Greek epics, drama and poetry never found their way into Muslim culture, which was based on a radically different value system. Now and again we do find a reference suggesting that the intellectual elite did hear of Homer, but that must have been about all: they had come across his name, and even that in a barely recognisable form. The maxims attributed to Homer thus did not originate with him, ${ }^{38}$

\footnotetext{
${ }^{34}$ Buzurg Ibn Šahriyār, op. cit., pp. 36-38.

${ }^{35}$ Szerb, Antal: A világirodalom története (A History of World Literature), Budapest, Magvető, 1973, p. 154.

${ }^{36}$ See The Odyssey, IX, pp. 231-240. Cf. Grunebaum, op. cit., p. 302.

${ }^{37}$ The Odyssey, X, pp. 229-347. In the last century, A. V. Gutschmid (Rheinisches Mu-
} seum XIX, 1864, p. 395), found close parallels with the beginning of The Acts of Andrew and Matthew, and so, more recently, did Grunebaum (op. cit., p. 304); but it is by no means clear that the Muslim world was at all familiar with this work.

${ }^{38}$ In the Fihrist, his encyclopaedic survey of the literature of his time, an-Nadìm makes two references to Homer (calling him "Amirüs"): once in a short list of names, the second time in connection with alchemy. Cf. The Fihrist of al-Nadìm. A Tenth-Century Survey of Muslim Culture, ed. and transl. by B. Dodge, New York, Columbia University Press, 1970, p. 676, p. 859. al-Bīrūnī, in his al-Ātār al-bāqiya (ed. E. Sachau, Leipzig, 1878, p. 86) compares Homer and Imru'l-Qays topically, which shows that he did not know Homer. Though aš-Šahristānī (al-Milal wa'n-nihal. ed. M. Saiyid al-Kīlān̄i, al-Qāhira, 1381/1961, pp. 106-108) and the Siwān al-hikma attributed to Abū Sulaymān as-Siğistānī (ed. D. M. Dunlop, The Hague-Paris-New York, Mouton, 1979, pp. 6. 13, 66, 96-100) "cite" him regularly, the cited words of wisdom are not from Homer. On the other hand, Hunayn ibn Ishạa Minor and had acquired a fine command of Greek, was said to be able to quote entire passages of Homer (See G. Strohmaier: Homer in Bagdad, Byzantinoslavica 41 (1980), pp. 196-200, cf. D. Gutas, Greek Thought, Arabic Culture. London-New York, Routledge, 1998, pp. 138, 140): he was, however, probably unique in this. The sayings attributed to Homer have been studied by J. Kraemer, who has proven them to be the gnomes of Menander. See: Arabische Homerverse, ZDMG 106 (1956), pp. 259-316; 107 (1957), pp. 511-518; and M. Ullmann: Die arabische Überlieferung der sogenannten Menandersentenzen. Wiesbaden, 1961. 
and we do not quite know what to make of the claim that Theophilus of Edessa (died 785), the favourite astrologer of the Caliph Mahdī (775-785), translated Homer into Syriac, for Homer was not translated into Arabic until the early twentieth century and it was done, even then, in an insufficient way. ${ }^{39}$

What all this boils down to (and this applies equally to all the other literary parallels as well ${ }^{40}$ is that there is no way of substantiating most of the putative instances of borrowing, though we cannot rule out the possibility that Muslim folk tradition adopted and preserved certain classical topoi in some indirect and constantly changing form.

Be that as it may, it is often very difficult to draw the line between "folk" and "highbrow" in the classical era of Muslim culture. For one thing, it was not the case that the former was an oral tradition, and the latter a written one. Harking back to pre-Islamic times, the oral tradition was always given priority in Muslim culture, whether the subject was poetry, the Koran, or the Islamic sciences. At the same time, though historians and storytellers alike relied primarily on oral tradition, both groups made substantial use of written sources as well. ${ }^{41}$

Nor is it true to say that folk tradition was necessarily based on fiction and higher culture on fact. The classical beginnings of "history telling" (coloured as these accounts were with elements borrowed from legends and fables) go back to the separation of two roles: the role of the hattib and that of the qāss (originally: the teller of religious tales in the mosque). Later the qāsș ventured outside the mosque, and went into the streets and the bazaar, and the stories he told - which, by then, were by no means purely religious - were likely to contain much more fiction than fact. Being more fictitious than factual, however, never excluded any of the several Arabic prose genres (which were permanently in a state of gradual transition) from the realm of highbrow culture: indeed, Kalila and Dimna (the Arabic version of the Pañcatantra) played a "Fables for Princes" function, and became a favourite with the cultural elite, as did the maqāma genre, whose picaresque stories and heroes drew heavily on the folk motifs of the streets. After al-Hamadhānī and al-Harīīi endowed the maqāma though most did so only by way of a brilliant literary exercise. ${ }^{42}$

All in all, two things do seem, nevertheless, to have distinguished the culture of the elite from folk culture: one was adherence to the formal criteria of scholarship

${ }^{39}$ It was Sulaymān al-Bustān̄̄'s rhymed 'Iliad' translation: Ilyādhat Hūmīrūs (al-Qāhira, 1904). About his rendering see A. Hámori's fine analysis: Reality and Convention in Book Six of Bustān̄̄'s 'Iliad'. Journal of Semitic Studies 1978, pp. 95-101.

${ }^{40}$ Another example is the Rukh motif, which Grunebaum (op. cit., p. 302) believes to have been borrowed from Lucian's True Story (II, 40), where mention is made of a halcyon 60 stadium in circumference. There is, however, no documentary evidence that the Arabic world of the time was familiar with Lucian's work.

${ }^{41}$ Cf. R. Irwin, op. cit., pp. 103-119.

${ }^{42}$ For more on maqāma, see the entry in the Encyclopedia of Islam (C. Brockelman - Ch. Pellat). See also Róbert Simon: Utószó (Postscript). In: A szüz és az asszony. Hamadāni és Hariri makámáiból (The Virgin and the Woman. The Maqāmāt of al-Hamadhānī and al-Harīīī). Budapest, Helikon, 1973, pp. 69-78; A. F. L. Beeston: Al-Hamadhānī, al-Harīn̄̄ and the maqāmāt genre. In: J. Ashtiany - T. M. Johnstone - J. D. Latham - R. B. Serjeant - G. R. Smith (eds): ${ }^{c}$ Abbāsid BellesLettres. Cambridge, Cambridge University Press, 1990, pp. 125-135. 
(which did mean a tendency to dispense with fictional elements or at least to assign them a subordinate or symbolic role); and the other, the use of ${ }^{c}$ arabiya, the normative classical Arabic of the Qur'ān, a strictly rule-bound, beautiful and highly-developed language. The two continue to function as the aesthetic norms of Arabic literature to this day, and continue to bar the literary recognition of vulgar fiction written in some vernacular, even in these last years of the twentieth century. Basically, of course, we are having to do with formal criteria, for even in the case of the hadit , containing the prophetic tradition, the emphasis is not so much on what is said (legendary elements aplenty are included), as how it is said - for it is this that is thought to vouch for the reliability of the tradition.

Even as elite culture drew on folk culture, so did folk literature seek to meet elite requirements. We see this in the great number of poems that have been included in The Arabian Nights (the second Calcutta edition has 1420 poems by 350 different poets $)^{43}$ - poetry being the most highly valued element of Arabic elite culture to this day. Other signs are the frequent use of $s a \breve{g}^{c}$, a form of rhymed prose popular from the mid-ninth century on, and the occurrence of passages which are explicit attempts to cater for the elite. Thus, for instance, in the tale of the seven-hundred and fifty-seventh night, the merchant Hasan commissions his slaves to find the most entertaining story for his lord, king Muhammad ibn Sabā'ik. After a lengthy search, one of his mamlūks finds an old man in Damascus who, in return for 110 dinars gives him a written copy of the story of Saif al-Mulūk and Badīcat al-ğamāl, on the following conditions: "That thou tell not this story in the beaten high road nor before women and slave-girls nor to black slaves nor feather-heads; nor again to boys; but read it only to Kings and Emirs and wazirs and men of learning, such as expounders of the Koran and others." $" 44$ The story pleased Hasan so much that he rewarded the mamlūk with ten horses, ten camels, ten mules, and three black and three white slaves; and then the king liked it so much that he gave Hasan an entire city, and appointed him grand vizier. It was, of course, the happy end that the authors and raconteurs of The Arabian Nights always dreamed of: not so much the tangible rewards, as the approbation of the elite. For they - as the story shows - were as much at home with writing and the written sources, as with the oral tradition.

One possible written (and oral) source of the Sindbad cycle is Captain Buzurg ibn Šahriyār's Kitāb ${ }^{c} a \breve{g} \bar{a}$ 'ib al-Hind (The Book of the Wonders of India), a collection of 134 stories, probably set down in writing around the middle of the tenth century. Enno Littmann already wrote of this anthology as a possible source. ${ }^{45}$ Veritably the folklore of the seafaring merchants who sailed the Indian Ocean and beyond, it is rich in tall tales inextricably combined with actual events. Little wonder that the Sindbad stories and Kitā ${ }^{c} a \breve{g} \bar{a} ' i b$ al-Hind contain so many parallels: the

\footnotetext{
${ }^{43}$ See J. Horovitz: Poetische Zitate in Tausend und Eine Nacht. In: Festschrift Eduard Sachau zum siebzigsten Geburtstage, hrsg. von G. Weil. Berlin, Verlag v. G. Reimer, 1915, pp. 375-379.

${ }^{44}$ Alf layla wa-layla. III, p. 271; R. Burton, op. cit., VII, pp. 308-314; E. Littmann, op. cit., IX, pp. 222-226.

${ }^{45}$ E. Littmann, op. cit., XII, p. 715.
}

Acta Orient. Hung. 53, 2000 
giant fish which misleads sailors, the "fish-island" motif, the diamond mountain, the Rukh and other giant birds, the snake island, and the monkey island all occur in both. ${ }^{46}$ Clearly, it is the yarns told day in and day out by the sailors and merchants passing through the busy ports on the Persian Gulf - Basra, Ubullah, and Sīrāf - that are the closest things that we have to the Sindbad cycle, though only a very small percentage of these tales was ever recorded. Besides Buzurg ibn Šahriyār's collection, there has come down to us also the Ahbār aș-Șin wa'l-Hind, an anonymous work dating from 851, a more scholarly account of the preceding century of trade with India and Ceylon, and a report of all the many things that were learned about these places. And though this account, too, has its share of folklore (the "fish-island" motif occurs here as well), ${ }^{47}$ it is the kind of book that would have provided storytellers with the background information they so sorely needed on the customs, flora, fauna and so on of India, Ceylon, and other exotic lands.

Last, but not least, we have another, though more sophisticated source or rather parallel to the episode of "burying alive" of the fourth Sindbad voyage which may serve a relative terminus a quo to its origins. It is a very illuminating story which is to be found in al-Faraj $b a^{c} d$ ash-shidda collected and partly written by al-qādī Abū'l-Qāsim at-Tanūkhī (327-384/938-994) not before 984. ${ }^{48}$ As R. Paret remarked, ${ }^{49}$ the compiler of this collection, besides his own experiences, utilised fairly well the works of his predecessors (al-Madā'inī, Ibn Abī'd-Dunyā and al-qāḍ̄ Abū'lHusayn), but for enriching his stories he heavily drew upon oral traditions, too. For this reason one leans to the opinion that it cannot be decided, whether the Sindbad story served eventually as a source to at-Tanūkhī, or on the contrary, the compiler of the Sindbad story borrowed this motive from the collection of the well-known qādi. All the same, on the basis of at-Tanūkhī's collection we may take for granted that the story itself was widespread and well-known around the mid-tenth century. There is however, one moment, which if we weighed the pros and cons of the priority, should be taken into account. The surprisingly well-knit and fascinating short story of alFaraj ba'd ash-shidda feigns to be a true historical report giving a number of pseudo historical details about the time of the plot as well as the identity and whereabouts of the hero and it tries to keep up the appearances of a hadith ${ }^{50}$ The name of the hero is Qubāt b. Razīn al-Lakhmī, a native of Fusțât in Cairo who participated in the days of $\mathrm{Mu}^{\mathrm{c}} \overline{\mathrm{a}} \mathrm{w} \overline{\mathrm{y}} \mathrm{a}$ in a campaign against the Byzantines and fell in captivity. After several vicissitudes he suffered through, his Byzantine custodian, al-bițrīq ar-Rakhān developed a friendly attitude towards him and one day he shared with him secrets of his

${ }^{46}$ Buzurg ibn Šahriyār, op. cit., pp. 12-14, 14-19, 36-38, 47, 66, 129.

${ }^{47}$ Ahbār as-Sìn wa'l-Hind, p. 1.

${ }^{48}$ al-Faraj $\mathrm{ba}^{c} d$ as-shidda. al-Qāhira: Maktaba al-Khānajī, Bagdad: Maktaba al-Muthannā, 1375/1955, pp. 144-153. On at-Tanūkhī see EI IV, pp. 655f. (R. Paret); 'Abbūd ash-Shaljī's Introduction to his Edition of the Nishwār al-mukhādara wa-akhbār al-mudhākara (The TableTalk of a Mesopotamian Judge), n.p., 1971, I, pp. 17-32.

${ }^{49}$ EI IV, p. 656.

${ }^{50}$ The matn of the story begins with a short isnād: rawā Najīd kātib Ibrāhīm b. al-Mahdī

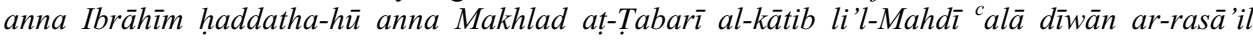
anna-hü kāna fì dīwān ${ }^{c}$ Abd al-Malik... (p. 144). 
adventurous past, and this is the point in the narration where the story of being buried alive comes up. The story abounds in seemingly true historical details and it is just this pseudo-historicity which is diametrically opposed to the timelessness of Sindbad's adventure devoid of all historical background. From this important difference we may draw the conclusion that the version imbedded in a rich historical setting should be the earlier, and the popular version deprived of its original social context must be of secondary use. Indeed, if we examine the Sindbad voyages whether they refer to real facts and historic persons, it turns out that they are poorly reflecting any concrete historical reality. ${ }^{51}$ The chart below would hopefully demonstrate the validity of our observation:

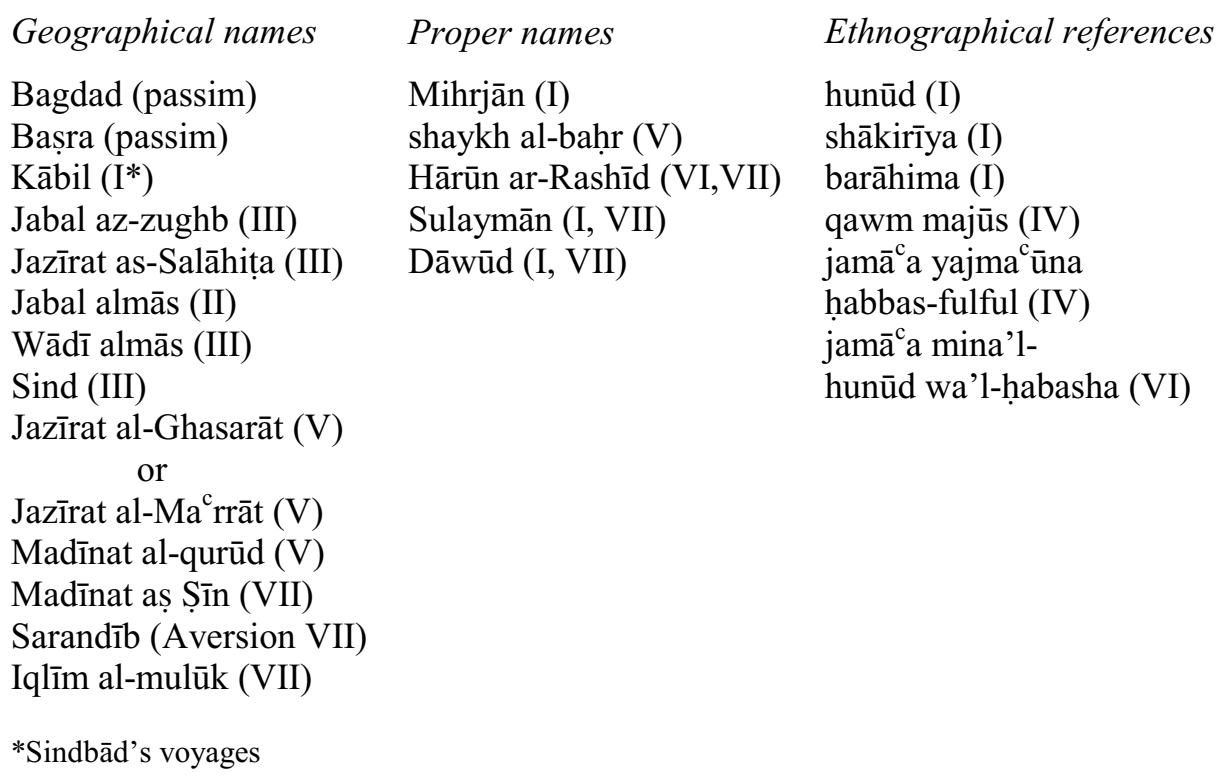

As it appears from these data, besides very few historical references as the stereotype mentioning of Baghdad and Bașra, we find a number of 'mythopoetic' names characteristic of the fictitious world of tales (like Jabal almās, Jabal az-zughb, etc.). The sea route of the different voyager is described by the same stereotyped expressions (wa-lam nazal musāfirīn min jazīra ilā jazīra wa-min baḥr ilā baḥr...). The world of fiction in the tales of Sindbad the seaman is not disguised and masked by real or pseudo-historical reports.

${ }^{51} \mathrm{C}$. Allibert has tried to localise the fabulous geography of the seven voyages in certain islands and other places of South-East Asia (Sumatra, Ceylon, Malacca, etc.) which may be probable but doesn't take into account the unequivocal tendency of the narrator to endow his narration with a deliberate mysterious character, see C. Allibert: Voyage aux 'Confins des mers du monde'. Le commerce arabe avec l'Asie du Sud-est à travers les sept voyages de Sindbad le marin. Topoi 6 (1996), fasc. 2, pp. 841-852. 


\section{Sindbad the man}

While the Faustian theme among the Northern peoples of Europe - observed Antal Szerb - is symbolised by the forest, the magical, its analogue in Arabian culture, is represented by the cave. "No far-off horizon here, no boundlessness, no open skies; and even the sea serves only to pitch the castaway onto some cavernous island. It's a dense, spellbindingly intense cavern world that we're in: secluded, blissful, and miserable." ${ }^{2}$ The cave, as we know, has been rich in symbolism since prehistoric times. Standing for the lap of Mother Earth, it is inseparably bound to life as well as death: the cave is where night resides, and where the underworld has its entrance. ${ }^{53}$

On four or five occasions in the Sindbad stories, caverns play a decisive role: they threaten the hero with certain death, but in the end, there is always a way out: to freedom, and even - in the "vivisepulture" episode in the Fourth Voyage - to symbolic rebirth.

We have already spoken of the precarious existence led by Muslim merchants, whose life was in constant jeopardy from at least two quarters. On the one hand, there were the high seas, where they plied their trade in luxury goods. Again and again, they faced the dangers of the uncertain seas and their strange inhabitants, chancing shipwreck and a prey to marauding pirates, with many a wealthy merchant finding himself, from one moment to the next, being sold as a slave (as, indeed, was Sindbad in the "A" variant of the Seventh Voyage). Reversals of fortune were always in the cards, though there was always also the chance of that exceptionally lucky break. The other source of uncertainty was built into the seafaring merchant's social status in Muslim society: a trader in luxury goods particularly was totally dependent on the caliph and his entourage, their favour assuring him the position and security that no wealth, however great, could buy in that patrimonial system.

All this made the Muslim merchant's world a rather "one-dimensional" one: they could not really build on their past achievements, nor be confident of future success. Every single undertaking stood as an isolated point in time, its success or failure contingent on nothing but chance, that elusive thing that people call "good luck" or "destiny". At any given moment, Sindbad stands to lose everything, even his life; and at any given moment, he stands to gain a great deal. Every venture he embarks on, his extraordinary good luck sees him through, but - like Weber's Protestant bourgeois or Pascal's wagering Christian - Sindbad, too, does everything within his power to make Allah help him, and so Allah does get him out of the most improbable situations.

Sindbad is both analogous to Weber's early capitalist entrepreneur, and the exact opposite. As regards his lifestyle, there is certainly nothing systematic about it; nor is there a limiting of consumption, nor asceticism with a view to accumulation: after every successful voyage, he reverts to the extravagant, pleasure-seeking habits of his youth. The similarity is that Sindbad too, is consistently God-fearing, and has an unquestioning faith in predestination. Sindbad's unconditional trust in Allah -

${ }_{53}^{52}$ Szerb, A., op. cit., p. 155.

${ }^{53}$ Cf. M. Lurker, Wörterbuch der Symbolik. Stuttgart, A. Kröner Verlag, 1991, pp. $320 \mathrm{ff}$. 
which we are safe to see as the explicit moral of all the Sindbad tales - has much to do with his deliverance time and again, and his symbolic rebirths.

And this brings us to the question of the relationship between Sindbad's character and his fate or fortune. The relationship between fate/fortune/chance and character became one of the vital problems in modern art and literature. Their connexion in this age, too, is far from being unequivocal but the nature of fate/fortune and its impact on individual character in pre- and postmodern times is more than problematic. ${ }^{54}$ Among the great many opinions we refer only to W. Benjamin's perplexing essay. ${ }^{55}$ According to him character is not a moral category and fate or fortune would not be a religious but an exclusively legal concept, and their relationship in most of the cases makes us most uneasy and embarrassed.

Indeed, Sindbad embodies, not unlike most of the pre- and postmodern 'dramatis personae', the paradoxical phenomenon of non-coincidence between fate and character which means that there is only a loose incidental and one-way contact between them. His static, unchanging nature practically brings on the blows of the heavy hand of fate. But none of his sufferings serves to mould his character: he is the same from the first voyage to the last. Sindbad - F. J. Ghazoul has noted ${ }^{56}-$ is an aesthetic, not a moral being: he has no sense either for the tragic or the comic in life. It is this that makes Sindbad so very modern, our contemporary, so to speak. He is, at the same time, a very ancient type, for whom destiny means adventure in the face of death, and survival against all odds and against all reason.

\footnotetext{
${ }^{54}$ See some useful assessments on these concepts: R. Eisler: Wörterbuch der philosophischen Begriffe. Berlin: E. Siegfried Mittler, 1910, s.vv. Charakter (pp. 196-199), Schicksal (pp. 1242f); Ph. P. Wiener (ed.): Dictionary of the History of Ideas. New York, Ch. Scribner's Sons, 1973, s.v. Fortune, Fate, and Chance (II, pp. 225-236. Vincenzo Cioffari).

${ }^{55}$ W. Benjamin: Schicksal und Charakter. In: Zur Kritik der Gewalt und andere Aufsätze. Frankfurt am Main, Suhrkamp, 1971, pp. 66-77.

${ }^{56}$ F. J. Ghazoul, op. cit., p. 72. For this reason the standpoint assumed by Peter D. Molan is not to be accepted (Sindbad the Sailor. A Commentary on the Ethics of Violence, JAOS 98 (1978), pp. 237-247). Violence is, indeed, an ethical concept but in Sindbad's case it has nothing to do with his character. It is, on the contrary, closely connected with his fortune/chance which has to be judged according to the legal preconditions of his times.
} 